ROCZNIKI HUMANISTYCZNE

Tom LXVII, zeszyt $9-2019$

DOI: http://dx.doi.org/10.18290/rh.2019.67.9-3

KRZYSZTOF KOSIOR

\title{
ODRODZENIE RELIGII W CHINACH PO MAO
}

\author{
THE REVIVAL OF RELIGION IN CHINA AFTER MAO
}

A b stract. The exposure of the agnostic character of Confucianism by Western sinologists has contributed to the unilateral perception of the Chinese religion as dominated by magical activity. The incompatibility of Chinese beliefs with theistic religions, which put God's presence or the personality of the deity in the foreground, caused the conviction of sinologists has been duplicated by Western researchers of religions. As a result of such an attitude, the residents of the Middle Kingdom were treated as superstitious or even non-religious.

Republican politicians, and after them the ideologues of the Maoist CPC, who fought against the "religious superstition," took it similarly. The persistence of "superstition" was supposed to stabilize social divisions, inhibit development and prevent the effective communication of the party with the people. However, forced atheism, contrary to the expectations of the Maoist communists, did not become a catalyst for uniting the nation or a tool for progress, but it sterilized people spiritually and as a result, instead of coexist peacefully, they sought for their own survival, also at the expense of others.

Mao died and was replaced by a pragmatic Deng. He and his successors adopted the view that the possible usefulness of religion suspends any prejudice against it. Moreover, where religion turns out to be useful in building the power of the country, it should be promoted and supported. However, this does not entail a declaration of full religious freedom. Besides, not all religions present in China are treated with equal favour. For various reasons, Chinese Buddhism is distinguished (Hàn chuán fójiào 汉传佛教). The activity of religious institutions is rationed and, in relation to various religions, accepted to a different degree.

The paper contains an analysis of the indicated and other aspects of the presence of religion in present-day China.

Key words: religion; China; Mao; Confucianism; Chinese Buddhism; Taoism; Christianity; Communist Party of China; the fight against "superstitions."

Dr HAB. Krzysztof Kosior, prof. UMCS - Uniwersytet Marii Curie-Skłodowskiej, Wydział Filozofii i Socjologii, Instytut Filozofii; adres do koresponedncji: P1. Marii Curie-Skłodowskiej 4, 20-031 Lublin; e-mail: krzykosior@wp.pl; ORCID: https://orcid.org/0000-0003$1424-1844$. 
Reporter i dalekowschodni korespondent amerykańskiej prasy Ian Johnson, autor szeroko dyskutowanej książki o współczesnym odrodzeniu religijnym w Chinach ${ }^{1}$, przytacza wypowiedź jednej z przepytywanych przez siebie osób, która dość dobrze ilustruje stan świadomości dzisiejszych mieszkańców Państwa Środka: „Myśleliśmy, że byliśmy nieszczęśliwi, bo byliśmy biedni. Ale teraz wielu z nas nie jest już biednych, a mimo to wciąż jesteśmy nieszczęśliwi. Zdajemy sobie sprawę, że czegoś nam brakuje i że tym czymś jest życie duchowe" ${ }^{\prime 2}$. Zdaniem autora kwestie wiary i wartości zajmują dziś centrum narodowej dyskusji nad sposobami organizacji życia Chińczyków w skali znamionującej duchowe odrodzenie, przypominające Wielkie przebudzenie (Great Awakening) w USA w wieku XIX ${ }^{3}$.

Przed podjęciem tej kwestii kilka słów o nieprzejrzystym w kontekście chińskim pojęciu religii. Współczesna nazwa zōngjiào (宗教) to neologizm, utworzony poprzez modyfikację oryginalnego chińskiego znaczenia przez Japończyków w XIX wieku (shūkyō) i reimportowany do języka chińskiego ${ }^{4}$ Kontrowersje budzi odnoszenie go do kulturowych fenomenów występujących we wczesnych Chinach przed powstaniem cesarstwa, jak i w Chinach cesarskich. Wątpliwości dotyczą stosowności czy adekwatności określania ich jako religii w znaczeniu oddawanym przez współczesną nazwę. Wątpliwości te zasiali pionierzy badań sinologicznych James Legge i Herbert Giles. Eksponując agnostyczny charakter konfucjanizmu, przyczynili się do jednostronnej percepcji religii chińskiej jako zdominowanej przez aktywność magiczną ${ }^{5}$ Niekombatybilność chińskich wierzeń z występującymi w religiach teistycznych, wysuwającymi na pierwszy plan obecność Boga bądź osobowość bóstwa, sprawiła, że przeświadczenie sinologów powielali zachodni religioznawcy. W następstwie takiego nastawienia mieszkańców Państwa Środka traktowano bądź jako przesądnych, bądź zgoła niereligijnych. Opinię badaczy zachodnich podchwycili uczeni chińscy. Filozof Hu Shih odnotował: „wykształceni ludzie w Chinach są indyferentni religijnie”.6.

\footnotetext{
${ }^{1}$ IAn Johnson The Souls of China: The Return of Religion after Mao (London: Penguin Books, 2017).

${ }^{2}$ Ibid., $16-17$.

${ }^{3}$ Ibid., 16, 18.

${ }^{4}$ W. E. SoothiLL, The Three Religions of China (London: Hodder and Stoughton, 1913), 6; obszerniej na ten temat: SUZUKI SHŪJI, „Religion $(s h \bar{u} k y \bar{o})$ and Freedom (jiyū $)$ ”, w: The Emergence of the Modern Sino-Japanese Lexicon. Seven Studies, red. Joshua A. Fogel (Leiden: Brill, 2015), 81-91.

${ }^{5}$ ChIng Kung YAng, Religion in Chinese Society: A Study of Contemporary Social Functions of Religion and Some of their Historical Factors (Berkeley: University of California Press, 1961), 4.

${ }^{6} \mathrm{Hu}$ SHIH, The Chinese Renaissance (Chicago: University of Chicago Press, 1934), 78.
} 
Inni poszli jeszcze dalej. Omawiający tę kwestię Anthony C. Yu przywołuje opinię historyka Guo Zhanbo, który w wydanej w 1973 r. Wspótczesnej historii Chin (Jìndài zhōngguó shř 近代中國史) stwierdza ni mniej ni więcej: „Chiny nie mają religii” (Zhōngguó gēnběn méiyǒu zōngjiào 中國 根本沒有宗教 $)^{7}$. Oto jak argumentuje swój pogląd: „Konfucjusz prowadził rozważania o ludziach, a nie o duchach, o życiu, nie o śmierci. I nie było to tylko osobiste nastawienie Konfucjusza, gdyż Chiny co do zasady nie mają żadnej religii. Religie do Chin przyszły z zewnątrz, zarówno buddyzm, jak też islam i chrześcijaństwo [...] Weźmy Księgę Przemian, jedną z najstarszych w Chinach. Zawiera głębokie prawdy, ale pozbawione religijnego charakteru. [...] Co można rzec o Wielkim Ostatecznym (taiji)? Jest zasadą, a nie bogiem. W Księgach Dokumentów i Pieśni często pojawiają się nazwy «Niebo» (tian) i «Pan na Wysokościach» (shangdi), ale są one używane w odniesieniu do ludzi. W ustaleniach dotyczących praw klanu i kultu przodków zastrzega się, że przodkowie winni być czczeni jak Niebo i stąd nauka, że «nie ma większej synowskiej miłości/nabożności (xiao) niż ofiara dla Nieba» [aluzja do Zapisków o rytuałach/obyczajach — Liji i 禮記 - K. K.]. Nawet to nie jest religia"8.

To redukcjonistyczne ujęcie, podzielane także przez innych chińskich uczonych, po części oddawało światowy trend cywilizacyjny, dążenie do sekularyzacji. Dokonywano także analizy porównawczej i ewaluacji, w której następstwie zdominowaną przez magiczny taoizm religię ludową w zestawieniu z narodotwórczym chrześcijaństwem określano jako haniebną i poniżającą Chińczyków. Tak czy owak mocno zarysowała się ideologiczna tendencja do klasyfikowania chińskiego dziedzictwa religijnego jako przesądu. Odnosząca się doń nazwa míxin 迷信 jest także zapożyczeniem japońskiego neologizmu (meishin).

Popełniano także inne uchybienie o charakterze religioznawczym. Do więcej niż połowy poprzedniego stulecia zachodni badacze podzielali przekonanie, że chińskie religie: buddyzm, taoizm i konfucjanizm stanowią analogię dla wywodzącej się z Abrahamowej tradycji trójcy: judaizmu, chrześcijaństwa i islamu. Wobec popularnego powiedzenia: „Trzy nauki, jedną nauką" (Sānjiào yījiāo 三教一家) to oczywista bzdura. Mimo to jednak owi uczeni, w okresie postępującej sekularyzacji mniemali, że tak jak dla ludzi Zachodu zaangażowanie religijne oraz jego skala jest dla Chińczyków

\footnotetext{
${ }^{7}$ Anthony C. Yu, State and Religion in China. Historical and Textual Perspectives (Chicago and La Salle: Open Court, 2005), 5.

${ }^{8}$ Ibid., 150.
} 
kwestią wyboru. Błąd sprostował socjolog Yáng Qìngkūn (Ch'ing-k'un Yang, 1911-1999), w świecie nauki znany jako Ching Kung Yang, który w swej pomnikowej, powstałej ponad pół wieku temu, ale wciąż aktualnej pracy, charakteryzującej chińską religijność przedstawił koncepcję religii „rozproszonej” (diffused religion), osadzonej w codziennej aktywności spełnianej w określonych warunkach społecznych ${ }^{9}$. Wykazał on, że np. przejawem uświęcenia pracy był kult bogów patronujących poszczególnym grupom zawodowym, co wydaje się pozostałością uwielbienia dla mitycznych herosów-dobroczyńców ludzkości, przejawem zaś uświęcenia lokalnej wspólnoty świątynna cześć dla bogów wioski czy dzielnicy albo też nieoddzielanie, a podyktowane pragmatyką łączenie poglądów i praktyk pochodzących z różnych wielkich tradycji religijnych. Gdyby nie szczęśliwy zbieg okoliczności, wskutek którego Yang na początku lat 30. minionego wieku trafił do USA, gdzie został profesorem uniwersytetu w Pittsburghu, na instruktywną wiedzę o chińskiej religijności czekalibyśmy jeszcze co najmniej dwie dekady, do otwarcia Chin po śmierci Mao.

Mao odszedł w 1978 r. Liberalny względem religii w swych wczesnych deklaracjach, stał się jej zagorzałym przeciwnikiem, obwiniając ją o hamowanie marszu Chin ku światowej hegemonii poprzez utrwalanie społecznych podziałów i utrudnianie komunikacji władzy z ludem. Mimo że w konstytucji z $1954 \mathrm{r}$. zadeklarowano wolność wyznania, partia komunistyczna podjęła działania zmierzające do wykorzenienia religijnych tradycji $\mathrm{i}$ - jak to określano - zerwania więzi łączących religijne wspólnoty $z$ feudalną przeszłością i pozbawić je związków z kolonialnymi czy imperialistycznymi strukturami obcych rządów.

Utrzymywane od wieków przeświadczenie o autarkicznym charakterze cywilizacji chińskiej i prymacie jej zdobyczy kulturowych, kultywowane przez autorytarną władzę, owocowało rozpowszechnieniem postaw i działań ksenofobicznych. W znacznej mierze dotknęły one sferę religii. Należy pamiętać, że Chiny mają za sobą długą, rozwiniętą w epoce Tangów (618906), tradycję kontroli aktywności religijnej cesarskich poddanych. Dlatego także religijną politykę władzy komunistycznej można postrzegać jako tej tradycji kontynuację. W cesarskich Chinach państwo (cesarz i, w mniejszej mierze, dwór oraz wyróżnieni lennicy) było suwerenem we wszystkich aspektach życia swych poddanych. Nie było rozdziału religii i państwa, tak jak jest on pojmowany na Zachodzie. Nie było go ani w teorii, ani w praktyce, a Chińczycy co do zasady nie kwestionowali suwerenności władcy. Ponadto cesarstwo podejmowało wysiłki zmierzające do „zapobiegania aktyw-

\footnotetext{
${ }^{9}$ YANG, Religion in Chinese Society, 20-21, 294-295.
} 
ności i powstrzymywania rozwoju ruchów religijnych identyfikowanych jako obce”. Podobnie KPCh z powodzeniem próbowała ograniczyć działalność religijną pośród grup i osób, które odmawiały współpracy $\mathrm{z}$ organizacjami religijnymi sponsorowanymi lub kontrolowanymi przez państwo. W okresie Rewolucji Kulturalnej (1966-1969; 1976) aktywność rządzących i zmobilizowanych przez partię, zorganizowanych $\mathrm{w}$ paramilitarne czerwono-gwardyjskie oddziały (Hóng wèibing 红卫兵) rzesz młodzieży była nad wyraz dolegliwa. Kampania przeciw religii nie zaczęła się jednakże po objęciu władzy przez komunistów w 1949 r., ale około siedemdziesiąt lat wcześniej, kiedy to konfrontacja $\mathrm{z}$ potężnym wówczas Zachodem doprowadziła do postępującego upadku cywilizacji chińskiej. Amok hunwejbinów wszakże doprowadził ją do zenitu. Katalizatorem zjednoczenia narodu i narzędziem postępu miała stać się przymusowa ateizacja, a właściwie, wzorowany na poważaniu mitycznych boskich dobroczyńców ludzkości, quasi-religijny kult Mao. Niestety partyjna ideologia duchowo wyjałowiła ludzi, przez co zamiast zgodnie współżyć, w skrajnych warunkach bytowych zabiegali o własne przetrwanie, także kosztem innych.

Romantyczną wizję i towarzyszącą jej ludobójczą politykę Mao szczęśliwie zastapił technokratyczny pragmatyzm Denga: „Religijna wiara ludzi nie obchodzi mnie dopóty, dopóki przestrzegają prawa i ciężko pracują"10. Tą wypowiedzią nawiązał do przytaczanego przez siebie przysłowia, które cnotę kota nakazuje upatrywać w jego użyteczności (łapaniu myszy), a nie w urodzie (maści). Stanowisko Denga sprawiło, że surowe ograniczenia w odniesieniu do praktyk religijnych zawieszono.

Konstytucja (Xiànfă 宪法) ogłoszona 4 grudnia 1982 r. ugruntowuje czworaki fundament chińskiego socjalizmu: dyktaturę ludu, myśl Marksa, Lenina i Mao, socjalistyczną drogę rozwoju i kierownictwo KPCh. Wprawdzie podkreśla znaczenie idei ostatniego z wymienionych klasyków, ale w sposób nadzwyczaj umiarkowany. Najbardziej interesujący dla nas jest artykuł 36, który dotyczy kwestii religii. Oznajmia się w nim co następuje:

„Obywatele ChRL cieszą się wolnością wyznania.

Żaden organ państwowy, organizacja publiczna ani żadna jednostka nie może zmuszać obywateli do uwierzenia albo niewiary $w$ odniesieniu do jakiejkolwiek religii; nie może także dyskryminować obywateli, którzy wierzą albo niewierzących jakiejś religii.

\footnotetext{
${ }^{10}$ Donald E. MACINNIS, „Secularism and Religion in China. Problem of Transcendence”, w: Contemporary Chinese Philosophy, red. Frederick J. Adelmann (The Hague: Martinus Nijhoff Publishers, 1982), 118.
} 
Państwo ochrania normalną [wyróżnienie K. K.] aktywność religijną [guójiā băohù zhèngcháng de zōngjiào huódòng 国家保护正常的宗教活动].

Nikt nie może używać religii do angażowania się w działania, które zakłócają porządek publiczny, osłabiają zdrowie obywateli albo kolidują z państwowym systemem edukacji.

Organy i sprawy religijne nie podlegaja jakiejkolwiek obcej dominacji [Zōngjiào tuántǐ hé zōngjiào shìwù bù shòu wàiguó shili de zhīpèi 宗教团体和宗教事务不受外国势力的支配]"11.

Ostatnia fraza jest niekiedy oddawana wyrażeniem: „kontroli obcych państw”. Wynika z tego, że religia w Chinach jest wyłącznie sprawą chińską, co oznacza, że żadna obca siła nie może sprawować kontroli nad nią, tak samo jak i nad innymi chińskimi sprawami. Pewną dyskusję wywołało słowo „,normalna” w odniesieniu do aktywności religijnej, ale na ogół zgadzano się, że w tym miejsu oznacza ono „legalna”. Innymi słowy, normalna aktywność religijna to taka, na którą zezwala państwo albo jego lokalni przedstawiciele.

Rozległa wykładnia artykułu Konstytucji została pomieszczona w dokumencie KC KPCh z 31 marca 1982 r. zatytułowanym „Podstawowy punkt widzenia i polityka dotycząca kwestii religijnej w okresie socjalizmu w naszym kraju" (Guānyú wŏguó shèhuì zhŭyì shíqi zōngjiào wèntí de jīběn guāndiăn hé jīběn zhèngcè 关于我国社会主义时期宗教问题的基本观点和 基本政策), powoływanym zwykle jako „Dokument 19” (Hijiǔ hào wénjiàn 十九號文件) ${ }^{12}$. Zrazu był przeznaczony do partyjnego użytku wewnętrznego (nèibù 内部). Wyciekł wszakże, wzbudził zainteresowanie i był często komentowany. Dlatego 19 czerwca 1982 r. został opublikowany w Czerwonym Sztandarze (Hóngqi 红旗), ideologicznym organie KPCh, i stał się podstawą wykładni prawnej sytuacji religii w dzisiejszych Chinach.

W „Dokumencie 19” podkreśla się wsparcie partii dla (konstytucyjnej) polityki wolności wyznania. Wyjaśnia się, że członkowie Partii mogą nie być wyznawcami jakiejkolwiek religii. Ponadto wskazuje na konieczność współpracy pracowników Partii i Biura ds. Wyznań z wiernymi w budowaniu

\footnotetext{
${ }^{11}$ Constitution of the People's Republic of China (Chinese and English Text), CongressionalExecutive Comission on China, dostęp 14 września 2018, https://www.cecc.gov/resources/legalprovisions/constitution-of-the-peoples-republic-of-china.

12 „Zhōnggòng zhōngyāng yìnfā (1982) 19hào wénjiàn 中共中央印發（1982）19号文件”, Huárén shénxué yuándi 華人神學園地, dostęp 14 września 2018, http://www.chinesetheology.com/ ChinaReligiousPolicy/19documentBIG5.htm; przekład angielski w: DANIEL E. MacInNIS, Religion in China Today: Policy and Practice (Maryknoll, N.Y.: Orbis Books, 1989), 8-26; Purdue University, Center on Religion and Chinese Society, dostęp 14 września 2019, https://www.purdue.edu/ crcs/wp-content/uploads/2014/08/Document_no._19_1982.pdf.
} 
socjalistycznego państwa. Należy zapewnić nieruchomości dla celów religijnych, a religijnych profesjonalistów wyszkolić tak, by byli biegli zarówno w sprawach religijnych, jak i politycznych oraz wspierać ich finansowo.

Osiem legalnych organizacji religijnych to związki: buddyjski, taoistyczny, islamski, a także pięć ugrupowań chrześcijańskich, w tym trzy katolickie: Patriotyczny Związek Katolicki, Komisja do Spraw Religijnych i Konferencja Biskupów oraz dwa protestanckie: Patriotyczny Ruch Potrójnej Autonomii (samowystarczalny, samorządny, samopropagujący się) i działająca przy nim Chrześcijańska Rada Chin. Działalność religijna poza nimi jest zabroniona. Organizacje są zobowiązane do przestrzegania wskazań partii i rządu.

Religia, jeśli ma przetrwać, musi wypełniać nałożony na nią obowiązek bycia „patriotyczną”, w tym sensie, że „nie może być żadnego przyzwolenia na posłużenie się w jakikolwiek sposób religijnym pretekstem w celu przeciwstawiania się kierownictwu partii albo dla zniszczenia jedności narodowej czy etnicznej" "13. Nawet jednak gdy te warunki będą spełniane, ani przyszłość religii, ani jej prosperowanie nie są zagwarantowane, jest ona bowiem zjawiskiem historycznym, reprezentującym określone stadium rozwoju ludzkości i wraz z postępem społecznym, ekonomicznym i edukacyjnym „religia ostatecznie zniknie z ludzkiej historii" ${ }^{\prime 4}$.

Partia, która jest forpocztą komunistycznego społeczeństwa, stanowiącego — w zamyśle jej przedstawicieli — ostatnie stadium procesu dziejowego, sama uprawnia się do wartościowania, oceniania tego, co już zaszło, i przewidywania tego, co jeszcze nastąpi. A co nastąpi, a raczej ma nastąpić, oznajmia się w „Dokumencie 19”.

Luzując rygory w odniesieniu do działalności związków wyznaniowych, partyjni przywódcy nie przewidzieli skali ożywiania religijnego, w szczególności we wspólnotach buddyjskich i chrześcijańskich. Aktywność tych ostatnich zyskała sobie nawet miano „chrześcijańskiej gorączki” (Jīdūjiào rè 基督 教热). Jednym $\mathrm{z}$ jej objawów była masowa akcesja do wspólnot wyjętych spod prawa. Pomna na udział chrześcijaństwa w upadku komunizmu w Europie oraz rolę, jaką buddyzm Tybetańczyków oraz islam Ujgurów odgrywają w ich dążeniach niepodległościowych, a dodatkowo będąc poddana naciskom płynącym z liberalnego Zachodu, „KPCh stała się coraz bardziej konserwatywna, a nawet reakcyjna w swojej polityce religijnej"15.

\footnotetext{
${ }^{13}$ MacInNIS, Religion in China Today, 21

${ }^{14}$ Ibid., 10.

${ }^{15}$ Tony LAmbert, „The Present Religious Policy of the Chinese Communist Party”, Religion, State \& Society 29 (2001), 2: 128.
} 
W listopadzie 1993 r. prezydent Jiang Zemin wydał trzy dyrektywy, dookreślające działalność „patriotycznych” organizacji religijnych. Obejmowały one obowiązki: (1) dokładnego i prawidłowego wdrożenia polityki religijnej partii, (2) wzmocnienia kontroli spraw religijnych tak, by były prowadzone zgodnie z prawem, oraz (3) pokierowania nimi tak, aby były kompatybilne $\mathrm{z}$ wymogami chińskiego społeczeństwa socjalistycznego. Zarazem Jiang podkreślił, że państwo „chroni normalną działalność religijną”, a jednocześnie „ogranicza i uderza w tych, którzy wykorzystują religię do prowadzenia działalności przestępczej"16. Polityka partii względem religii była później uściślana jeszcze kilkukrotnie, zwykle w reakcji na wydarzenia, które w opinii jej przywódców zagrażały stabilności państwa.

Kiedy sekretarzem generalnym KPCh w 2012 r. został Xi Jinping, spodziewano się, powołując się na religijne zaangażowanie i sympatie członków jego rodziny, dalszego rozluźnienia partyjnej kontroli. Niestety zamiast tego administracja Xi ośmieliła partyjną frakcję, która już dominowała przed jego wyniesieniem, a którą opisuje się jako „wojujących ateistów”. Niejako spłacając jej trybut, na ogólnokrajowej konferencji poświęconej religii, odbytej wiosną 2016 r., Xi potwierdził dominację partii nad religijnymi instytucjami. Oznajmił, że sprawy religijne mają dla KPCh „szczególne znaczenie”. Powiedział wówczas: „Powinniśmy oddziaływać na kręgi religijne i ich zwolenników, kształcąc je, przywołując socjalistyczne wartości podstawowe i kierować religijnymi ludźmi ideami jedności, postępu, pokoju i tolerancji [...] Grupy religijne muszą zgłębiać zasady i idee, które pozostają w zgodzie z harmonią społeczną i postępem oraz są korzystne w budowaniu zdrowego i cywilizowanego społeczeństwa, oraz interpretować doktryny religijne w sposób, który sprzyja rozwojowi współczesnych Chin i jest zgodny z naszą wspaniałą kulturą tradycyjną". Ponadto ostrzegł, że niektóre formy aktywności religijnej mogą być kanałami „zagranicznej infiltracji” i skutkować naruszaniem prawa. W związku z tym wezwał członków KPCh, by pozostali „nieustępliwymi marksistowskimi ateistami, utrwalali swoje przekonanie i mieli na uwadze partyjne zasady" ${ }^{\prime 17}$. Z kolei na ostatnim zjeździe KPCh w październiku 2017 r. oznajmił: „Religie w Chinach powinny być chińskie w swym ukierunkowaniu, a partia zapewni im aktywne kierownictwo, aby mogły dostosować się do socjalistycznego społeczeństwa"18.

\footnotetext{
${ }^{16}$ Ibid., 124-125.

17 „China Focus: Xi calls for improved religious work”, Xinhuanet, dostęp 14 września 2018, http://www.xinhuanet.com/english/2016-04/23/c_135306131.htm.

${ }^{18}$ LI YUAN. „At the Congress Xi reaffirms: Sinicization of religions under the Communist
} 
Charakteryzując stosunek komunistycznej władzy do religii, Pitman B. Potter stwierdza: „Regulacja religii odzwierciedla politykę partyjną, przyznającą ograniczoną autonomię przyjętym praktykom, próbując jednocześnie stłumić te wyzywające polityczną ortodoksję. Legalność pozostaje kluczowym składnikiem nie tylko jako podstawa skutecznej regulacji rządowej w zakresie, w jakim może ona uzyskać powszechne poparcie dla oficjalnych preferencji, dotyczących równowagi między autonomią a lojalnością. Zdolność reżimu do podtrzymywania legalności i regulowania religii pozostaje jednak niepewna, ponieważ użyteczność i skuteczność kontroli pozostaje kwestionowana" 19 .

Z kolei cytowany już Ian Johnson wprost wskazuje na czynnik ograniczający poczynania władzy. Odnotowuje wprawdzie: „Tradycyjne wartości i praktyki są promowane jako źródło stabilności i moralności”, zaraz po tym jednak podkreśla: „Ale zarazem istnieje lęk przed wiarą jako ostatecznie niekontrolowalną siłą - alternatywną ideologią do rządowej wizji tego, jak społeczeństwo powinno być zarządzane" ${ }^{20}$.

Odnosząc się do sytuacji, w jakiej znajdują się religie w Chinach, należy uwydatnić, że nawet te uznane za legalne nie są traktowane jednakowo. Mimo że chrześcijaństwo w następstwie powodzenia misji nestoriańskiej jest obecne w Chinach od 635 r., to niemal nieprzerwanie jest uważane za obce. Popularne powiedzenie: „Jednego chrześcijanina więcej; jednego Chińczyka mniej” (Duō yīgè jīdū tú; shăo yīgè zhōngguó rén 多一个基督徒。少一个中 国人) ilustruje niekompatybilność „,chrześcijańskiego” z ,chińskim”. Współcześnie opór wobec chrześcijaństwa to skutek bolesnych zabiegów modernizacyjnych, podejmowanych u schyłku i po zniesieniu władzy mandżurskich Qingów, w trakcie których prowadzono walkę z rodzimymi religiami, wyrzucając im kultywowanie przesądów (míxin 迷信). Chrześcijanie stali się mimowolnymi sojusznikami znienawidzonej władzy. Na przełomie poprzednich stuleci (1899-1901) wybuchło w Chinach antychrześcijańskie, choć faktycznie skierowane przeciw nadającym przywileje „zamorskim diabłom” Qingom, powstanie bokserów (quán luàn 拳亂).

Chrześcijaństwo zostało uderzone rykoszetem. Ruch przeciw przesądom (făn míxin yùndòng 反迷信运动), który miał doprowadzić do upadku kultu świątynnego i pozbawić majątku sprawujących nad nim pieczę kapłanów

Party”, AsiaNews.it, dostęp 14 września 2018, http://www.asianews.it/news-en/At-the-CongressXi-reaffirms:-Sinicization-of-religions-under-the-Communist-Party-42096.html

${ }^{19}$ Pitman B. Potter, „Belief in Control: Regulation of Religion in China”, The China Quarterly 2003, No. 174 (Jun.): 337.

${ }^{20}$ JoHnson, The Souls of China, 32. 
taoistycznych i buddyjskich oraz spirytystycznych mediów, został zainicjowany edyktem cesarza Guangxu (Guāngxù 光緒) z lipca 1898 r., nakazującym przekształcenie świątyń (wyjąwszy te związane z kultem państwowym) w szkoły. Dokument powstał w środowisku konfucjańskich reformatorów i stanowił wyraz panujących $\mathrm{w}$ nim postaw fundamentalistycznych i antyklerykalnych. Fundamentalizm przejawiał się w odrzucaniu wszelkich idei i praktyk nieobecnych w konfucjańskich pismach kanonicznych, antyklerykalizm zaś wyrażał się $\mathrm{w}$ sprzeciwie wobec instytucjonalizacji religii, w szczególności zawodowych duchownych, utrzymujących się z posług liturgicznych i aktywności postrzeganej jako magiczna ${ }^{21}$. Kampania, której przyświecały hasła „Zniszcz świątynie, buduj szkoły” (huľ miào bànxué 毀 廟辦學) czy też „Buduj szkoły za świątynny majątek” (miào chăn xīngxué 廟產興學) spotkała się ze społecznym odzewem, choć jej efekty były niejednoznaczne i zróżnicowane w odniesieniu do warstw współtworzących społeczeństwo chińskie po upadku cesarstwa.

Lud skłaniał się raczej ku kultywowaniu rodzimych tradycji religijnych, podczas gdy elity polityczne republikańskich Chin dostrzegały w chrześcijaństwie czynnik modernizacji państwa. Warto odnotować, że zarówno Sun Jat-sen (Sūnyìxiān 孫中山), jak i Czang Kai-szek (Jiăngjièshí 蔣介石) wybrali konwersję - Sun został baptystą, Czang zaś katolikiem, a synteza etyki konfucjańskiej i chrześcijańskiej legła u podstaw Ruchu Nowego Życia (xīn shēnghuó yùndòng 新生活運動), który miał na celu odnowę moralna i duchową narodu. W ramach jego aktywności prowadzono kampanię „zniszczenia przesądów". Z kolei od pierwszych dni komunistycznych rządów chrześcijaństwo zostało uznane za sojusznika obcego imperializmu, a tym samym za żywotne zagrożenie dla Chin. Mimo że dość dobrze w lokalnych wspólnotach zadomowione, wciąż jest traktowane jako zdominowane przez siły obce.

Podejrzenia, jakkolwiek znacznie słabsze, są kierowane także pod adresem buddystów i taoistów. Buddyzm, także obca religia i w cesarskiej przeszłości wielokrotnie przez władzę pod tym pretekstem atakowana, jest jednak religią zsinizowaną w stopniu czyniącym ją bardzo odległą od indyjskiego oryginału i dlatego naturalizowaną. Dodatkowo w okresie republikańskim został on poddany znaczącym reformom. Ich ideową podstawę stanowiła koncepcja humanistycznego buddyzmu, buddyzmu „dla ludzkiego życia” (rénshēng fójiào 人生佛教) albo „dla ludzkiego świata” (rénjiān

\footnotetext{
${ }^{21}$ Vincent GoOSSAERT. „1898: The Beginning of the End for Chinese Religion?”. Journal of Asian Studies 65 (2006), 2: 308-309.
} 
fójiào人間佛教), sformułowana i propagowana przez mnicha o imieniu Taixu (Tàixū 太虛; 1889-1947) ${ }^{22}$. Jego reformistyczne dążenia motywowały dwa wydarzenia. Pierwszym była republikańska rewolucja z 1911 r., która prócz wielu innych bolączek obnażyła przerażający stan buddyzmu, cechujący się degeneracją i dezintegracją religijnej wspólnoty. Duchowieństwo na ogół zaniedbywało edukację i osobistą praktykę, a swą aktywność ograniczało do wykonywania obrzędów pogrzebowych i innych rytuałów. Drugim wydarzeniem, motywującym reformatorskie idee Taixu, był dialog, który prowadził z chrześcijańskim ewangelistą, norweskim misjonarzem luterańskim Karlem L. Reicheltem (1877-1952), założycielem chrześcijańskiego centrum Tao Fong Shan (Dàofēng shān 道風山) w Hong Kongu. Dyskusja z pastorem sprawiła, że uświadomił sobie siłę własnej religii. Skrytykował chrześcijański teizm i nabył przeświadczenia, że buddyzm może dać chrześcijaństwu to, czego mu wówczas brakowało, a mianowicie religijnego ducha, który nie sprzeciwiałby się współczesnej nauce i, podkreślając jego ponadnarodowy charakter, mógłby stać się fundamentem powszechnego zaufania i wspólnoty. Żywiąc przekonanie, że odnowiona buddyjska doktryna jest zdolna do zjednoczenia wszystkich istniejących form cywilizacji i jako taka powinna rozprzestrzenić się na całym świecie, nawiązał kontakty z buddystami różnych denominacji z Chin i innych krajów azjatyckich, w szczególności ze Śri Lanki, Tajlandii i Japonii. W największym skrócie mówiąc, jego modyfikacja buddyzmu polegała na przesunięciu ośrodka skupienia ze śmierci i losów pośmiertnych na aktualnie żyjącego człowieka, który uświadomiwszy sobie wartość daru życia, jest w stanie stać się cnotliwą osobą. Wzorem był dlań przyszły założyciel buddyzmu, w okresie poprzedzającym nirwanę, kiedy to był oddany poszukiwaniu drogi do ustania cierpienia. Idee wynikłe $z$ tej modyfikacji miały stać się zaczynem do konstruowania buddyjskiego raju, czyli Czystej Krainy tutaj, w świecie aktualnie żyjących ludzi (rénshēng jìngtǔ 人生 净土).

Reformatorska myśl Taixu, zrazu umiarkowanie popularna, stopniowo zyskiwała uznanie i kontynuatorów, w szczególności pośród mnichów i świeckich wyznawców na Tajwanie. $Z$ kolei ich rozległa aktywność oddziałała na odradzającą się wspólnotę buddyjską w ChRL, a w skali bardziej ogólnej ujawniła ekspansjonistyczny charakter chińskiego buddyzmu. Interpretujący to zjawisko Hung-yok Ip odnotowuje: „Chińscy buddyści zobowiązali się do

\footnotetext{
${ }^{22}$ DARUi Long, „Humanistic Buddhism From Venerable Tai Xu to Grand Master Hsing Yun”, Hsi Lai Journal of Humanistic Buddhism 1 (2000): 58-66; Don Alvin PitTMan, Toward a Modern Chinese Buddhism: Taixu's Reforms (Honolulu: University of Hawai Press, 2001).
} 
uczynienia swojej religii globalną i do wzmocnienia znaczenia buddyzmu w różnych wymiarach społeczeństwa chińskiego w szczególności i ogólnie w ludzkim życiu"23.

Pierwszoplanowym przejawem tej ekspansji jest dziś zjawisko cyberbuddyzmu, produkcja i rozpowszechnianie cyfrowych ,skarbów dharmy” (făbăo 法宝), elektronicznych utensyliów, informatycznych systemów i programów, mających kluczowe znaczenie w tworzeniu i utrzymywaniu lokalnych, ponadregionalnych i międzynarodowych sieci wyznawców i sympatyków, korzystających $\mathrm{z}$ nowoczesnych mediów ${ }^{24}$. Ich wykorzystywanie w komunikacji społecznej ułatwia wymianę poglądów i obiektów religijnych zarówno w świecie chińskim, jak i poza nim, a uczestniczący w niej stale zwiększają swój udział w przepływie informacji, obrazów, dźwięków, więzi społecznych i towarów ${ }^{25}$.

Zasięg oddziaływania buddyjskich treści z wykorzystaniem nowych technologii jest przeogromny i jeszcze się zwiększy, albowiem „nie ma wątpliwości, że cyfrowa obecność buddyzmu rozszerzy się jeszcze bardziej, ponieważ technologie te przenikają każdy zakątek naszego życia"26. Ocena adekwatności i trwałości efektów tej niezwykłej, względem tradycyjnej, aktywności misyjnej i pastoralnej jest wszakże kwestią przyszłości.

W odniesieniu do praktyki współczesny chiński buddyzm (Hàn chuán fójiào 汉传佛教) jest synkretyczną formą religijną z dominacją dwóch rodzimych tradycji, reprezentujących odmienne i poniekąd skrajne typy religijności: dewocyjnej jìngtǔ 凈土 i kontemplacyjnego chánu 禅. Taka religijna konfiguracja umożliwia omijanie doktrynalnych, rytualnych i organizacyjnych raf, ujawniających się $\mathrm{w}$ funkcjonowaniu religii teistycznych, i zawiesza właściwą im konfrontacyjność. Jako taka może być traktowana jako jeden z przejawów miękkiej siły, sprzyjającej chińskiej ekspansji na Zachód.

Komunistyczna Partia Chin postrzega rozwój buddyzmu w Chinach jako dogodny z jeszcze kilku powodów ${ }^{27}$. Pierwszy to promocja kraju, ocieplenie jego wizerunku poprzez sprzyjanie turystyce pielgrzymkowej z krajów buddyjskich i zachodnich. Korzysta na tym chińska dyplomacja, szczególnie w

\footnotetext{
${ }^{23}$ HyUNG-YOK IP, „Buddhist Activism and Chinese Modernity”, Journal of Global Buddhism 10 (2009): 146.

${ }^{24}$ Francesca TAROCCO, „Technologies of Salvation: (Re)locating Chinese Buddhism in the Digital Age”, Journal of Global Buddhism 18 (2017): $156 \mathrm{n}$.

${ }^{25}$ Ibid., 167.

${ }^{26}$ DANiel Veidlinger, „Introduction”, w: Buddhism, the Internet and Digital Media: The Pixel in the Lotus, red. Gregory Price Grieve i Daniel Veidlinger (New York, London: Routledge, 2015), 9.

${ }^{27}$ ANDRÉ LALIBERTÉ, „Buddhist Revival under State Watch”, Journal of Current Chinese Affairs 40 (2011), 2: $109 \mathrm{n}$.
} 
stosunkach z krajami, w których buddyzm jest liczącą się religią. Drugi powód wiąże się z dochodowością takiej turystyki. I nie chodzi tu wyłącznie o zyski bezpośrednie. Turyści, obdarowując buddyjskie instytucje, pomnażają ich majątek. Ten zaś jest wykorzystywany na działalność charytatywną, która w jakimś stopniu umniejsza niepożądane skutki chińskiej rewolucji kapitalistycznej. Władza sprzyja tej aktywności, widząc w niej okazję do „harmonizowania społeczeństwa” poprzez kultywowanie więzi międzyludzkich. Trzeci powód, być może najważniejszy, wiąże się ze współpracą między stowarzyszeniami buddystów chińskich i tajwańskich, która łagodzi napięcia występujące między Chińską Republiką Ludową i Republiką Chińską. Nie jest to bezpośrednie działanie na rzecz politycznego zjednoczenia - Republika Chińska odrzuca projekt ,jeden kraj, dwa systemy” (yīguó liăngzhi 一国两制) - ale tworzenie warunków zgodnego rozwoju społeczeństw obu chińskich krajów.

Zainicjowana u schyłku cesarstwa i kontynuowana w okresie republiki kampania przeciwko przesądom objęła także taoizm. Faktycznie w ciagu wieków namnożyło się w nim krocie magicznych zabiegów, celujących w zachowanie witalności i efektywnej długowieczności, a nawet cielesnej nieśmiertelności. Znajdującą się u ich podstawy ideę jednostkowej przemiany, okazjonalnie, bo w sytuacji zaistnienia niesprzyjających okoliczności politycznych, wiązano z ideą zmiany społecznej — przywrócenia czy też zapanowania mitycznego status quo ante - idealnego Niebiańskiego Królestwa Wielkiego Pokoju (tàipíng tiānguó 太平天国), wspólnoty, w której każdy działa samowładnie, spontanicznie, naturalnie, zgodnie ze swym przyrodzonym uposażeniem (zìrán 自然). W niespokojnych czasach schyłku Hanów i w okresie Wei-Jin (220-420) kluczowe pojęcie zìrán zaczęto odnosić do sposobu zachowania pozostającego w przeciwieństwie do oficjalnego stylu życia i obyczajów. To nowe użycie pojęcia pomogło usprawiedliwić odmowę służby czy podległości aktualnej władzy jako wyższą formę zachowania, a nie jako akt nielojalności ${ }^{28}$. Tak, w wielkim uproszczeniu, narodził się taoistyczny anarchizm, który stał się zarzewiem licznych buntów ludowych, począwszy od rebelii żółtych turbanów (huángjīn zhī luàn 黃巾之亂; 184-189) po wielkie, zasięgiem i liczbą ofiar odpowiadające raczej wojnie domowej, powstanie Taipingów (1851-1864). Dlatego także to, co robią taoiści, nie może być wolne od kontroli.

\footnotetext{
${ }^{28}$ John A. RAPP, Daoism and Anarchism. Critiques of State Autonomy in Ancient and Modern China (London, New York: Continuum-Bloomsbury, 2012), b.n.s.
} 
Co do wyznawców islamu (yīsillán jiào 伊斯兰教), to uważa się ich, wbrew uniwersalnemu posłaniu ich religii, za mniejszość etniczną. Islam bowiem nie jest religią Hanów, a ludów Huízú i Wéiwú'ěr, czyli Ujgurów.

Z kolei religijny charakter odradzającej się praktyki konfucjanizmu (rú 儒), nieobjętego wykazem legalnych religii, gdyż w dzisiejszych Chinach jako taki (jako religia) nie jest oficjalnie rozpoznawany, to temat na odrębny i obszerny artykuł. Należy wszakże odnotować, że o ile w czasach maoistowskich był on symbolem porządku feudalnego, jego doktryna samorozwoju była tematem tabu, a zainteresowanych jej kultywowaniem traktowano jako wyznawców „reakcyjnej sekty” (făndòng huìdàomén 反動會道門), to po dwudziestoletnim okresie debat nad jego możliwym znaczeniem dla rozwoju współczesnych Chin, a więc od początku XXI wieku, stał się zjawiskiem niemal masowym i przedmiotem ukierunkowanego zaangażowania ze strony władzy, wykorzystującej konfucjańskie dziedzictwo w szeregu społecznych inicjatyw. Pośród nich największą popularność zyskał ruch zachęcający dzieci (i rodziców) do uczenia się na pamięć i recytowania treści dzieł klasycznych (értóng dújing yùndòng 儿童读经运动). A utworzenie ogólnoświatowej sieci Instytutów Konfucjusza jako emanacji chińskiej „miękkiej siły” sprawiło, że postać ongiś wyklętego mędrca urosła niemal do rangi globalnego symbolu socjalistycznych $\mathrm{Chin}^{29}$.

Obraz rzeczywistości religijnej w Chinach nie byłby pełny bez choćby wzmianki o sektach działających bez przyzwolenia władz. Powstawały w okresach politycznych zawirowań, których w dziejach Państwa Środka nie brakowało, na ogół z wizją eschatologicznej zmiany społecznej. Spełniały szereg potrzeb i aspiracji, których realizacja w obrębie uznanych religii była utrudniona bądź zgoła niemożliwa. Daniel L. Overmeyer zalicza do nich: uzyskanie pewności poprzez uczestnictwo w grupowym rytuale i wzajemne wspieranie się w dążeniu do celu religijnego, zapewnienie środków do autokultywacji i duchowego rozwoju, w tym dostępu do wiedzy ezoterycznej, moralne przewodnictwo, nadzieję na odnowę polityczną i społeczną, organizację samoobrony (także militarnej) przed opresją władzy oraz ekonomicznej samopomocy, dostęp do technik uzdrawiania i sztuk walki oraz podniesienie statusu kobiet ${ }^{30}$. Wzorcową organizacją był działający na początku $\mathrm{V}$ wieku, a następnie kilkakrotnie odradzający się w zmodyfikowanych for-

\footnotetext{
${ }^{29}$ DAvid Alexander PAlmer, „Religion in the Peoples' Republic of China: An Overview”, ResearchGate, dostęp 14 września 2018, https://www.researchgate.net/publication/265345777 Religion in the Peoples' Republic of China: An Overview.

${ }^{30}$ DAniel L. Overmyer, „Alternatives: Popular Religious Sects in Chinese Society”, Modern China 7 (1981), 2 (Apr.): 157-169.
} 
mach „Biały Lotos” (báilián白蓮). Modyfikacje w charakterystyce głównych idei (formułując je, najpierw czerpano z koncepcji buddyjskich, później także $\mathrm{z}$ taoistycznych i z wierzeń ludowych) oraz różnice $\mathrm{w}$ odniesieniu do skali zaangażowania sił i środków sprawiły, że należy go postrzegać raczej jako typ organizacji, a nie jako spójną tradycję ${ }^{31}$. W epoce Mingów (13681644) do sekt wzorujących się na „Lotosie” i pokrewnych przylgnęło określenie „heretyckich doktryn” (xiéjiào 邪教), za panowania komunistów przydano temu wyrażeniu znaczenie ,złych kultów”. Nie zabrakło ich w ostatnim ćwierćwieczu, a za najbardziej zagrażające porządkowi społecznemu uznano masowy ruch Falun Gong, czyli „Praktykowanie Koła Dharmy” (fălúngōng 法轮功), wykorzystujący wybrane elementy doktryn buddyzmu i taoizmu, łączący postawę moralną z ćwiczeniami medytacji i gimnastyki oraz quasichrześcijańskie zgromadzenie „Błyskawica ze Wschodu” (dōngfāng shăndiàn 东方闪电), którego wyznawcy wierzą, że Wszechmogący Bóg wcielił się w chińską kobietę.

Analizujący religijność współczesnych Chińczyków Hongyi Lai akcentuje jej ludowość i ziemskość, stwierdza bowiem, że Hanowie, stanowiący przytłaczającą większość mieszkańców Państwa Środka, a między nimi zwłaszcza buddyści i taoiści, zwracają się do religii głównie z powodów utylitarnych, spodziewając się powodzenia w życiu doczesnym, mając nadzieję, że siły nadprzyrodzone przyniosą im korzyści materialne ${ }^{32}$. Wskazując z kolei na przyczyny odrodzenia religijnego po erze Mao, wymienia odstapienie przez państwo od zakazu religii, spadek atrakcyjności oficjalnej ideologii oraz rosnąca potrzebę zaspokojenia psychologicznej potrzeby bezpieczeństwa ludności w obliczu szybkiej modernizacji, zwiększenia komercjalizacji i dyslokacji społecznej ${ }^{33}$. Analogiczny, wyjąwszy niebudzący wątpliwości fragment o satysfakcjonowaniu zintensyfikowanej potrzeby bezpieczeństwa, pogląd głosi Daniel L. Overmyer, oznajmiając, że odnowiona polityka władz państwowych uwolniła stłumione w ludziach pragnienie religii i umożliwiła im znalezienie w niej alternatywy dla ideologii komunistycznej ${ }^{34}$.

Yoshiko Ashiwa uważa taką interpretację za niewystarczającą, ponieważ zakłada ona ostry podział okoliczności związanych z religią przed i po $1979 \mathrm{r}$. Odwołując się do analizy empirycznych szczegółów ożywienia religijnego

\footnotetext{
${ }^{31}$ Ibid., s. 169.

${ }^{32}$ Hongy LaI, „The Religious Revival in China”, Copenhagen Journal of Asian Studies 18 (2003): 41, 58 .

${ }^{33}$ Ibid., 59

${ }^{34}$ DANiEL L. Overmyer, „Religion in China Today: Introduction”, The China Quarterly 2003, No. 174 (Jun.): 307.
} 
po śmierci Mao, takich jak interakcja między państwem a organizacjami religijnymi, w tym także konflikty i sytuowanie się religii względem ideologii politycznych, pokazuje, że podstawy do powstania przestrzeni dla religii w nowoczesnym państwie, jakim są dzisiejsze Chiny, są efektem długotrwałego procesu. Dlatego wyjaśnienie współczesnego odrodzenia religii powinno wykraczać poza okres od czasu nowej państwowej polityki religijnej, wprowadzonej w 1979 r., a nawet poprzedzający założenie Chińskiej Republiki Ludowej. Jej zdaniem interpretacja religijnego przebudzenia „musi być zakorzeniona $\mathrm{w}$ ziarnach projektów nowoczesności zasianych na przełomie XIX i XX wieku, z których wyłoniła się przestrzeń religijna"35.

Kampania przeciw przesądom zainicjowana w 1898 r. poniosła fiasko. Odrodzenie religijne, które nastąiło po odejściu Mao, wykazało, że religia chińska jest znacznie bardziej odporna, niż ktokolwiek sobie wyobrażat ${ }^{36}$. Jej żywotność, zrazu nadwątlona, następnie nabrała mocy, co sprawiło, że po okresie odreagowywania maoistowskiej traumy, od początku XXI wieku „duchowe i religijne tęsknoty i aspiracje Chińczyków znajdują coraz bardziej zróżnicowane możliwości wyrażania się"37. Dlatego należy odnotować, że religia Chińczyków przeszła w tym stuletnim procesie cały szereg zmian. Ostatecznie to nic dziwnego, bo zmiany (yì 易) są wpisane w chiński światopogląd od zarania kultury.

\section{BIBLIOGRAFIA}

Ashiwa, Yoshiko. „Positioning Religion in Modernity: State and Buddhism in China”. W: Making Religion, Making the State. The Politics of Religion in Modern China, red. Yoshiko Ashiwa i David L. Wank, 43-73. Stanford: Stanford University Press, 2009.

DARUI LONG. „Humanistic Buddhism From Venerable Tai Xu to Grand Master Hsing Yun”. Hsi Lai Journal of Humanistic Buddhism 1 (2000): 58-66;

Goossaert, VinCENT. „1898: The Beginning of the End for Chinese Religion?”. Journal of Asian Studies 65 (2006), 2: 307-335.

Hongyi LaI. „The Religious Revival in China”. Copenhagen Journal of Asian Studies 18 (2003): $40-64$.

Hu Shin. The Chinese Renaissance. Chicago: The University of Chicago Press, 1934.

HYUNG-YOK IP. „Buddhist Activism and Chinese Modernity”. Journal of Global Buddhism 10 (2009): 145-192.

\footnotetext{
${ }^{35}$ Yoshiko Ashiwa, „Positioning Religion in Modernity: State and Buddhism in China”, w: Making Religion, Making the State. The Politics of Religion in Modern China, red. Yoshiko Ashiwa i David L. Wank (Stanford: Stanford University Press, 2009), 48.

${ }^{36}$ GOOSSAERT, ,1898: The Beginning of the End for Chinese Religion?”, 331.

${ }^{37}$ PALMER, „Religion in the Peoples' Republic of China”.
} 
Johnson, IAn. The Souls of China: The Return of Religion after Mao. London: Penguin Books, 2017.

LALIBERTÉ, ANDRÉ. „Buddhist Revival under State Watch”. Journal of Current Chinese Affairs 40 (2011), 2: 107-134.

LAmbert, TONY. „The Present Religious Policy of the Chinese Communist Party”. Religion, State \& Society 29 (2001), 2: 121-129. DOI: https://doi.org/10.1080/09637490120074800.

Overmyer, DAniel L. „Alternatives: Popular Religious Sects in Chinese Society”. Modern China 7 (1981), 2 (Apr.): 153-190.

Overmyer, DANIEL L. „Religion in China Today: Introduction”. The China Quarterly 2003, No. 174 (Jun.): 307-316.

MacInnis, Daniel E. Religion in China Today: Policy and Practice. Maryknoll, N.Y.: Orbis Books, 1989

MACINNIS, DANIEL E.: „Secularism and Religion in China: Problem of Transcendence”. W: Contemporary Chinese Philosophy, red. Frederick J. Adelmann, 117-133. The Hague: Martinus Nijhoff Publishers, 1982.

Pittman, Don Alvin. Toward a Modern Chinese Buddhism: Taixu's Reforms. Honolulu: University of Hawai Press, 2001.

Potter, Pitman B. „Belief in Control: Regulation of Religion in China”. The China Quarterly 2003, No. 174 (Jun.): 317-337.

Rapp, John A. Daoism and Anarchism. Critiques of State Autonomy in Ancient and Modern China. London, New York: Continuum-Bloomsbury, 2012.

SoothiLL, W. E. The Three religions of China. London: Hodder and Stoughton, 1913.

SuZUKI SHūJI. „Religion (shūkyō) and Freedom (jiyū)”. W: The Emergence of the Modern SinoJapanese Lexicon. Seven Studies, red. Joshua A. Fogel, 81-112. Leiden: Brill, 2015.

TAROCCO, Francesca. „Technologies of Salvation: (Re)locating Chinese Buddhism in the Digital Age”. Journal of Global Buddhism 18 (2017): 155-175. DOI: http://dx.doi.org/10.5281/ zenodo. 1284254.

Veidlinger, DANiEl. „Introduction”. W: Buddhism, the Internet and Digital Media. The Pixel in the Lotus, red. Gregory Price Grieve i Daniel Veidlinger. New York, London: Routledge, 2015.

Yang, Ching Kun. Religion in Chinese Society. A Study of Contemporary Social Functions of Religion and Some of their Historical Factors. Berkeley: University of California Press, 1961.

Yu, Anthony C. State and Religion in China. Historical and Textual Perspectives. Chicago, La Salle: Open Court, 2005.

\section{ŹRÓDŁA SIECIOWE}

„China Focus: Xi calls for improved religious work”. Xinuhanet. Dostęp 14 września 2018. http://www.xinhuanet.com/english/2016-04/23/c_135306131.htm.

Constitution of the People's Republic of China (Chinese and English Text). CongressionalExecutive Comission on China. Dostęp 14 września 2018. https://www.cecc.gov/resources/ legal-provisions/constitution-of-the-peoples-republic-of-china.

Li YuAN. „At the Congress Xi reaffirms: Sinicization of religions under the Communist Party”. AsiaNews.it. Dostęp 14 września 2018. http://www.asianews.it/news-en/At-the-Congress-Xireaffirms:-Sinicization-of-religions-under-the-Communist-Party-42096.html.

Palmer, David Alexander. „Religion in the Peoples' Republic of China: An Overview”. ResearchGate. Dostęp 14 września 2018. https://www.researchgate.net/publication/265345777 Religion in the Peoples' Republic of China: An Overview.

Purdue University, Center on Religion and Chinese Society. Dostęp 14 września 2018. https://www.purdue.edu/crcs/wp-content/uploads/2014/08/Document_no._19_1982.pdf. 
„Zhōnggòng zhōngyāng yìnfā (1982) 19hào wénjiàn 中共中央印發 (1982) 19号文件”. Huárén shénxué yuándi 華人神學園地. Dostęp 14 września 2018. http://www.chinesetheology.com/ ChinaReligiousPolicy/19documentBIG5.htm.

\section{ODRODZENIE RELIGII W CHINACH PO MAO}

\section{Streszczenie}

Eksponowanie agnostycznego charakteru konfucjanizmu przez zachodnich sinologów przyczyniło się do jednostronnej percepcji religii chińskiej jako zdominowanej przez aktywność magiczną. Niekombatybilność chińskich wierzeń z religiami teistycznymi, wysuwającymi na pierwszy plan obecność Boga bądź osobowość bóstwa, sprawiła, że przeświadczenie sinologów powielali zachodni religioznawcy. W następstwie takiego nastawienia, mieszkańców Państwa Środka traktowano bądź jako przesądnych, bądź zgoła niereligijnych. Podobnie rzecz ujmowali zwalczający „religijny zabobon" politycy republikańscy, a po nich ideolodzy maoistowskiej KPCh. Jego utrzymywanie się miało stabilizować społeczne podziały, hamować rozwój i uniemożliwiać efektywną komunikację partii z ludem. Przymusowa ateizacja jednak, wbrew oczekiwaniom maoistowskich komunistów, nie stała się katalizatorem zjednoczenia narodu ani narzędziem postępu, ale wyjałowiła ludzi duchowo, przez co zamiast zgodnie współżyć, zabiegali o własne przetrwanie, także kosztem innych.

Co więcej, tam gdzie religia okazuje się być pożyteczna w dziele budowy potęgi kraju, należy ją promować i wspierać jej rozwój. Nie wiąże się to wszakże z deklaracją pełnej wolności religijnej. Poza tym nie wszystkie obecne w Chinach religie są traktowane $\mathrm{z}$ równą przychylnością. $\mathrm{Z}$ różnych względów wyróżniany jest chiński buddyzm (Hàn chuán fójiào 汉传佛教). Aktywność instytucji religijnych jest reglamentowana i w różnym stopniu, w odniesieniu do różnych religii, akceptowana.

W artykule analizuje się wyżej wskazane i jeszcze inne aspekty obecności religii w dzisiejszych Chinach.

Slowa kluczowe: religia; Chiny; Mao; konfucjanizm; buddyzm chiński; taoizm; chrześcijaństwo; Komunistyczna Partia Chin; walka z „zabobonem”. 